\title{
Preputial Gland/Clitoral Gland
}

National Cancer Institute

\section{Source}

National Cancer Institute. Preputial Gland/Clitoral Gland. NCI Thesaurus. Code C117978.

A laboratory specimen consisting of the preputial gland and the clitoral gland. 